\title{
The Resilience and Adaptative Strategies of Italian Cooperatives during the COVID-19 Pandemic
}

\author{
Ermanno Tortia* \\ Associated Professor, Department of Economics and Management, ermanno.tortia@unitn.it \\ University of Trento, 5 Via Vigilio Inama, 38122 Trento (TN), Italy \\ Roberta Troisi \\ Associated Professor, Department of Political Sciences and Communication, rtroisi@unisa.it \\ University of Salerno, 132 Via Giovanni Paolo II, 84084 Fisciano (SA), Italy
}

\begin{abstract}
$\mathrm{T}$

hird sector organizations, like the rest of the economic system, have been heavily affected by the pandemic. The aim of this work is to study resilience and adaptability to crisis in terms of economic results and innovative outcomes of the cooperative business model in the Italian third sector during the COVID pandemic. This study uses new evidence from a recent survey on this sector and consists of two main parts. In the first, the institutionalist literature on contractual failures is assumed as an interpretative key in the comparison between the business models, governance, and routines in social cooperatives versus other non-profit organizations (NPOs) interpreted as third sector entities. In the second, we use the new data from a third sector survey in the Marche region, collected in the late spring of 2021 toward the end of lockdown measures. Empirical

assumptions concern organizational resilience and adaptation to unexpected negative shocks in cooperatives and other NPOs. The results show that, in the management of the crisis, cooperatives are better able to preserve their human capital and resort to layoffs less often than other NPOs. Shared decision-making, employee involvement, and the adaptability of the work process emerge as dominant organizational characteristics that support resilience and service innovation in cooperatives. The main policy implication concerns the ability of cooperatives to play a stabilizing and a-cyclical role during a crisis and to fill the supply gaps left open by other organizational forms (private, non-profit and the public sector). The originality of this paper lies in the new approach to cooperative organizations and in the analysis of the reaction of cooperatives during the pandemic crisis
\end{abstract}

Keywords: cooperative enterprises; third sector; COVID-19 pandemic; resilience; contractual failures; governance; economic performance; service innovation

Citation: Tortia E., Troisi R. (2021) The Resilience and Adaptative Strategies of Italian Cooperatives during the COVID-19 Pandemic. Foresight and STI Governance, 15(4), 78-88. DOI: 10.17323/25002597.2021.4.78.88

\footnotetext{
* Corresponding author.
} 


\section{Introduction}

The specialized literature reports that cooperatives behave differently from other organizational forms in relation to at least two fundamental organizational dimensions [Perotin, 2013; Borzaga et al., 2021]. The first refers to the adaptability of the business model, i.e., the economic strategies and market responses, in the face of a crisis [Jensen, 2013; Burdin, 2014]. The second refers to the adaptability of organizational characteristics in responding to unforeseen events. As regards the first notion, cooperatives show a stable development pattern that tends to not be very reactive to the economic cycle, that is, they grow less than average during expansionary periods and contract less during recessions and crisis. The economic literature has shown that this stable pattern corresponds to a more rigid supply curve than other economic organizations, since cooperatives tend to plan their growth in the medium to long term to meet their members' needs [Borzaga et al., 2021]. Several empirical tests have confirmed this theoretical implication [Bartlett et al., 1992], for example, in the case of Italy [Pencavel et al., 2006]. Wide literature reviews can be found in [Bonin et al., 1993; Pérotin, 2013].

In this vein, several contributions have analysed the behaviour of cooperatives during the financial crisis of 2008-2011 and the sovereign debt solvency crisis of 2012-2014. A case study on a group of worker cooperatives in Mondragon, in the Basque region of Spain, showed how this business model can accomplish a virtuous synergy between financial, industrial, and commercial activities within the same group to overcoming the crisis by suffering only marginal employment losses, a record in stark contrast to the rest of the Spanish economy in the same period [Ellis et al., 2018].

The survey in the second part of the paper concerns social cooperatives, which are defined by the law as a socially oriented, multi-stakeholder cooperative type [Borzaga, Galera, 2016; Sacchetti, Borzaga, 2020]. Depending on the definitions, legislation, cultural background, and institutional evolution, cooperatives are included among third sector organizations and nonprofit enterprises in some, but not all countries. In Italy, all types of cooperative enterprises (consumer, producer, worker, user, credit, housing, and social cooperatives) are defined by law as non-profit enterprises, as they are all required to reinvest at least $30 \%$ of their positive net residuals in indivisible reserves of capital, which cannot be shared between members either during the life of the organization or at the end of it [Tortia, 2021]. Social cooperatives in Italy mainly provide social services, a sector that offers a unique opportunity for comparison between different organizational forms (public, non-profit, and private), in particular, social cooperatives and other non-profit organizations (NPOs).

The adaptability of the business model is a guiding criterion in understanding resilience, since the governance rules and routines of cooperative enterprises are based on involvement and participation in decisionmaking of various non-investor stakeholders, a feature most often absent in other models [Cheney et al., 2014]. Scholars have focused on the specific organizational design and strong organizational identity of cooperatives, based on a broad set of values and principles [Nelson et al., 2016]. Their specific organizational capabilities can help adaptation to environmental change and support relationships with stakeholders that contribute to better resilience and innovation in an emergency such as a pandemic. This is particularly true because cooperatives are locally embedded and can leverage local social capital, relationships, and resources [Billiet et al., 2021]. Cooperative governance, together with their organizational routines and mutual benefit goals, form the backbone of their business model [Jensen, 2013].

The reactions of cooperatives to crisis situations are aimed at satisfying their members' needs and requests, which mainly concern the preservation of employment and production levels in worker and producer cooperatives and the guarantee of a stable flow of goods and services in other cooperative forms (e.g., users, credit unions [Borzaga et al., 2021]). To achieve members' objectives and stabilize employment during the crisis, cooperatives can reduce labor costs and cause wages to fluctuate, but they can also accept losses and reduce capital reserves [Mihazaki, Neary, 1983; Craig, Pencavel, 1993; Burdín, Dean, 2012; Navarra, 2016].

The first step of our analysis takes into consideration the institutionalist literature on contractual failures and how these are related to the development of cooperative enterprises. Second, some elements of evolutionary theory are taken into consideration to show how cooperatives autonomously develop their own working rules and organizational routines to respond to stakeholder demands and deal with negative shocks. In the second part of the paper, we use new data from a survey on the Italian third sector in the Marche region, including both social cooperatives and other NPOs. By comparing the determinants of economic performance and service innovation in the two groups, we are able to show the stability and resilience of the cooperative business model during the pandemic.

\section{Theoretical Insights: Contractual Failures, Governance Rules, and Organizational Routines in the Cooperative Business Model}

This section aims to reconstruct the micro-analytic elements that can differentiate behavioral outcomes in cooperatives from other organizational forms, both IOFs and other third sector organizations, during the current crisis to deliver testable hypotheses and contribute to building a new framework of empirical analysis. We consider the institutionalist theory of contractual failures and its impact upon the working of cooperative governance as a special kind of systemic organizational solution. 
The outstanding literature has shown the ability of cooperatives to face negative economic contingencies by adapting their internal structure and distributive patterns. Workers' cooperatives react to the crisis by lowering wages and making them more flexible in order to limit layoffs as much as possible [Pencavel et al., 2006; Roelants, Sanchez-Bajo, 2011; Perotin, 2013; Albanese et al., 2015], credit cooperatives by limiting credit crunch to firms in difficulty more than commercial banks would [Angelini et al., 1998], consumer cooperatives by lowering the prices of their products to make them accessible to their members [Mori, 2014], and social cooperatives by lowering the service fees and expanding supply rather than contracting it [Borzaga, Galera, 2016].

The current pandemic conditions show some similarities, but also substantial differences when compared to previous crises, having been characterized by sudden and simultaneous contractions of both supply and demand [Barua, 2020; Didier et al., 2021]. In the context of a health emergency and falling demand, third sector organizations can react by resorting to non-market resources such as volunteering and charitable donations, and by lowering the prices of their services thanks to the flexibility of labor costs and the organizational model. Consistently, some third sector activities, in particular care services, could overcome the crisis better than the rest of the economy, or even expand supply [Borzaga, Galera, 2016].

\section{Contractual Failures and Governance}

The new institutional literature explains investor ownership as the dominant model of property rights and insists upon the importance of specific investments, contractual failures, and opportunism as its determinants [Williamson, 1975]. The specificity of assets is positively correlated with increased contractual costs due to contractual incompleteness and the risk of opportunistic behaviors of non-controlling stakeholders. Investor ownership represents the best institutional tool for protecting specific investments and preventing opportunism in terms of haggling, shirking and holdup. In the Hansmann [Hansmann, 1996] model, investor ownership is still identified as the dominant proprietary form but compared on par with the other forms. Its primacy is not taken for granted but explained in efficiency (cost minimization) terms. Ownership is assigned to the stakeholder group that is able to minimize the sum total of transaction costs attached to the working of the organization, as sub-divided into the costs of the market contracting and the costs of ownership. Nothing, in principle, prevents stakeholder-patrons from becoming owners and, indeed, Hansmann shows that this possibility is especially observed on agricultural markets (agricultural cooperatives) and in some sectors populated by non-profit organizations. Also, non-investor-ownership is widespread in professional activities such as professional partnerships, in which most investments are embodied in human capi- tal and not in physical assets. In this regard, cooperative enterprises can be highly efficient organizations compared to IOFs due to the lower agency costs, but only when their members have homogeneous characteristics and preferences to avoid inflated transaction costs in terms of decision-making [Iliopoulos, Valentinov, 2018]. As for non-profit organizations, which constitute the third sector in the US, they are defined by Hansmann as organizations without owners (they are financed by philanthropic donors and governed by trustees), as they are created to pursue their social missions in an exclusive way, while control rights assigned to any stakeholder group would introduce unwanted private interests in their management and distribution patterns.

Starting from these premises, the ability of the organizational structure to absorb negative shocks has to do with the flexibility of its business model, which can allow for regaining sustainability and growth in difficult times. Organizational flexibility is here understood as the ability to change and adapt, especially in unpredicted or even emergency conditions. While important environmental shocks surely represent serious challenges and can endanger firm survival, they do also represent opportunities to do away with outdated organizational models and routines and pursue in novative goals in a pro-active way. Flexibility is partly based on the self-organization of work teams and the creation of positive feedback from experimentation [Englehardt, Simmons, 2002]. The ability to pursue alternative future scenarios is linked to the development of dynamic capabilities and flexible routines, which help achieve a proper balance between standardization, flexibility, and innovation in organizational processes. Flexible routines support resilience through the loose coupling between structured and performative organizational patterns, whose interactions favor the emergence and selection of new practices and strategies [Feldman, Pentland, 2003; Grote et al., 2009].

Organizational flexibility guided by ad hoc working rules and routines supports the internalization and management of negative external shocks and contractual imperfections, potentially improving efficiency [Poledrini, Tortia, 2020]. The new institutional literature in the classical works by [Commons, 1950; Ostrom, 1990, 2005] has insisted upon the importance of governance as a complex set of dedicated rules that are directed toward managing economic relations and resources by means of involvement, incentives, constraints, and sanctions. When these arguments are applied to cooperative enterprises, it can be stated that the ability to absorb negative shocks can be found at the very origins of the cooperative movement. Organizational resilience is substantiated in the stability of employment and of the supply of goods and services, depending on the fulfilment of members' needs [Weick, Sutcliffe, 2007; Lampel et al., 2014; Borzaga et al., 2021]. In consumer cooperatives, client involvement and co-production are essential for achieving better quality of goods, lower prices, and the reduction of posi- 
tional power on the market. Worker cooperatives, on the other hand, can overcome the imperfections of the employment relationship, since the risks of bilateral opportunism and abuse of power can be limited by including workers in decision-making, which has been shown to support stronger wage flexibility and employment stability [Navarra, Tortia, 2014; Albanese et al., 2015].

On the other hand, the cooperative form of business also faces fundamental challenges that can prevent the achievement of economic and financial sustainability. Especially: (i) financial difficulties in the absence of direct access to markets for equity capital [Jensen, Meckling, 1979]; (ii) different typologies of collective action failure, especially opportunism and free rider, as inscribed in the classic tragedy-of-the-commons social dilemmas [Hardin, 1968; Alchian, Demsetz, 1972]; and (iii) high proprietary and governance costs due to heterogeneous members' preferences and objectives [Hansmann, 1996]. Consequently, the study of the governance of collective action in productive organizations, after the seminal work of [Ostrom, 1990], requires a dedicated scientific approach focused on self-produced working rules that are able to guarantee involvement and the fulfillment of members' needs while, at the same time, forestalling opportunism and self-seeking distortions [Ostrom, 1990; Hansmann, 2013; Tortia, 2021].

In Italy, the social cooperative, as defined by law $381 / 1990^{1}$, represents the most recent cooperative form in Italy and is positioned at the crossroads between the traditional cooperative forms and the non-profit form of business. The social cooperative is required by law to have an explicit social goal and multi-stakeholder governance supporting the involvement of different constituencies and achieving goals that are not purely mutualistic but also directed toward producing social value [Hansmann, 1980; Borzaga, Galera, 2016; Sacchetti, Borzaga, 2020; Poledrini, Tortia, 2020]. Social cooperatives share important features with both worker and consumer cooperatives, since workers are almost always present in their membership, while, at the same time, their social mission and multi-stakeholder governance favor a high degree of involvement of volunteers, customers, users, and beneficiaries, a feature which clearly tends to expand their objectives towards the production of greater social value [Tortia, 2020].

\section{The Reactions of Social Cooperatives and Other Non- Profit Entities to the Pandemic}

National labor market statistics in Italy show that conventional firms reacted to sharp falls in demand by reducing supply and increasing layoffs when legal con- straints and public subsidies do not intervene. In this respect, starting from the beginning of March 2020, all companies have been prevented from laying off permanent workers, while public subsidies have dealt with the payment of reduced rates to redundant workers. These restrictions have been progressively lifted starting from July 1, 2021. Pre-COVID normality should be restored by the end of October $2021 .^{2}$

Considering the reactions to the pandemic of third sector organizations, including social cooperatives, it is possible to expect significant differences compared to IOFs. As concerns cooperatives, they have been identified as organizations that mostly intervene in times of crisis, as the creation of a new collective venture can help the system to reduce poverty and unemployment, softening the rough edges of the business cycle [Roelants, Sanchez-Bajo, 2011]. Their ability to withstand crisis can be explained by their effort to preserve their most valued resources, especially human capital, and redistribute emerging losses inside their own boundaries among their members and intertemporally. They strive to keep their supplies stable during a crisis and even fill the space vacated by private enterprises (as long as this is made possible by lockdown measures during a pandemic [Borzaga et al., 2021]). To this end, sustainability and resilience are supported by flexible working hours, smart working, lower and fluctuating wages, lower product prices, and price discrimination. Intertemporally, deferred payments and de-accumulation of reserves can shift temporary increases in costs and the reduction of revenues in the future. ${ }^{3}$ In turn, a smaller reduction in economic activity implies a smaller quantitative reduction in the amount of transactions that they are willing to carry out and smaller increases in unemployment. By improving their own resilience, they also counter systemic failure.

As for non-profit organizations, they are legally defined in Italy in a similar way to most other countries, in particular as associations, foundations, and religious entities that reinvest any positive residuals in indivisible reserves $^{4}$ and use all their assets to pursue their social missions (through an asset lock). They play a leading role and complement public supply in delivering social services. On the other hand, a less pronounced entrepreneurial attitude, a looser institutional structure (the Italian civil code does not regulate non-profit organizations as enterprises, but as simple non-profit entities), and a stronger reliance on non-market resources, such as voluntary work and charitable donations, may imply that non-profit organizations find it difficult to reach economic and financial sustainability during a crisis with negative consequences for employment and production [Hoogendoorn, 2011]. Furthermore, since

\footnotetext{
http://base.d-p-h.info/fr/fiches/premierdph/fiche-premierdph-441.html

2 As of 26 December 2021, a new extension for the redundancy block until 31 December 2021 was introduced for all workers in the service sector, crafts, small businesses and three industrial sectors: textiles, clothing and leather goods.

${ }^{3}$ https://www.nytimes.com/2020/12/29/business/cooperatives-basque-spain-economy.html [Accessed 30 June 2021].

${ }^{4}$ Pursuant to Legislative Decree 460/1997, NPOs are subject to the prohibition of distributing, even indirectly, profits and operating surpluses as well as funds, reserves or capital during the life of the entity, and the obligation to devolve the assets of the entity in the event of its dissolution for any reason, to other non-profit organizations of social utility or for purposes of public utility.
} 
most non-profits are not created for running production processes in an entrepreneurial way, they may encounter more difficulties in innovating service provision [Anheier, Kendall, 2001; Sparviero, 2019].

Given these premises, our hypotheses revolve around how resilience depends upon the adaptability of the business model, for example as regards the amount of capital assets, and whether social cooperatives prefer to increase the negative balance between costs and revenues during a crisis and accept greater losses rather than dismissing redundant workers. They also enquire how resilience depends upon the ability of the organizational model to adapt the supply of services to the needs that emerged during the pandemic and, consequently, upon the degree of organizational change and flexibility and service innovation [Mobiny, Soster-Ramos, 2020].

\section{Empirical Analysis}

This theoretical approach to cooperative governance allows us to formulate several empirically verifiable implications on how the cooperative business model, as defined by its governance rules, organizational routines, and managerial models, has dealt with the pandemic crisis compared to other third sector NPOs. We elaborate two main empirical hypotheses relating to the economic resilience of the organizational model and to organizational flexibility as a determinant of service innovation. The hypotheses are divided into several sub-hypotheses that refer to some fundamental organizational dimensions.

Our dependent variable in the OLS regressions is expressed in terms of the percentage increase in costs versus revenues during the pandemic in relation to the same results in previous years, separately for cooperatives and other NPOs. As determinants of economic results, we consider some organizational dimensions and their choices in regard to changes in the provision of services and innovation. Hypothesis 1 states:

HP1. We hypothesize that the economic resilience of the cooperative business model compared to other NPOs in terms of its ability to reduce costs in excess of revenues depends upon its adaptability across some salient organizational dimensions. We consider the following organizational drivers of performance:

HP1. A. Cooperative enterprises preserve employment levels and human capital during the crisis thanks to their ability to internally manage and partially overcome some contractual imperfections in the employment relationship (especially wage rigidity, excess layoffs, and depletion of human capital) better than other organizational forms. Consequently, we hypothesize that the amount of employment and its variation over time in cooperatives is more loosely correlated or not correlated with economic performance, as cooperatives prefer to reduce wages and make them flexible during a crisis rather than lay off worker-members;

HP1. B. Given the non-profit nature of social cooperatives and other NPOs, it is assumed that both organizational types are helped by volunteers in coping with a crisis and that an increase in the number of volunteers helps reduce excess costs during a crisis;

HP1. C. External pressures coming from the pandemic crisis and related social demands push both organizational types to introduce new services and to innovate in the provision of existing ones.

In the second step of the analysis, we estimate two logistic regression models to evaluate the impact of the variables describing the degree of organizational flexibility on: (1) providing new services in cooperatives; (2) providing traditional services through new delivery methods in the other NPOs. Hypothesis 2 states

HP2. We hypothesize that the resilience of the business model depends upon its ability to adapt the services provided to the needs that emerged during the pandemic and, consequently, upon its degree of organizational flexibility and adaptability to support organizational change and service innovation. Two sub-hypotheses are stated as follows:

HP2. A. Service innovation depends upon the degree of organizational flexibility in terms of the adaptability of decision-making processes when decisions are: fully shared by all stakeholder groups vs proposed by employees and when the timeliness of the decision-making process is guaranteed;

HP2. B. Service innovation depends upon the adaptability of the organizational model in terms of adaptability of the members' skills and adaptability of the work organization.

\section{Methodology and Data Sources}

The survey was conducted as part of a larger project that involved three Italian regions located respectively in the north, center, and south of Italy and characterized by a homogeneous incidence of third sector nonprofit organizations by the number of inhabitants. In this article, we focus on the Marche region of central Italy. A total of 452 responses were collected, with a response rate of $22.6 \%$, in line with other published work using web surveys on non-profit organizations [Curtis et al., 2010]. A distinctive feature of this region, which has captured our interest, lies in the territorial impact of third sector organizations, which are homogeneously located between urban and extra-urban areas. These organizations are widespread throughout the Marche region and have grown over the years, showing a positive balance between mortality and the creation of new entities [ISTAT, 2020]. In particular, in the case of social cooperatives, their number is growing in terms of staff hired and the value of production on total re- 
gional GDP. The contribution of the non-profit sector to the regional GDP is about $10 \%$ against $8 \%$ at the national level (the data refer to the period from 2011 to 2016)..$^{5}$ In the same period, the trend of new hires is positive (+14\%).

Two thousand organizations were randomly selected from the latest available regional register of non-profit organizations (BUR n.138 28/12/2017), invited by email and surveyed from April to June 2021. The survey consists of 29 multiple-choice and open-ended questions, which deal with the two main themes of the adaptability of the business model and of the organizational characteristics in responding to unexpected events. As regards the first theme, the questions are based on a similar survey conducted by Istat (Italian National Institute of Statistics) on the response of profit companies to COVID-19 [ISTAT, 2020]. Regarding the second theme, the questions were chosen on the basis of the existing literature that defines the determinants of adaptability as derived from internal decisionmaking processes, work organization models, and employee skills [Hatum, Pettigrew, 2006].

\section{The Variables}

The variables used in the OLS regressions are described as follows. The dependent variable of interest is the percentage change in net costs (costs minus revenues) recorded in 2020 with reference to the same measure in the three years prior to COVID-19 (from 2017 to 2019). According to our data, this variation is always negative. The result is not surprising given that we are dealing with a period of crisis. However, it can have different degrees. It can therefore reasonably be argued that a smaller negative change in net revenues indicates a better ability to respond to the crisis.

We consider a host of explanatory variables: (1) the number of employees; (2) the variation in the number of employees recorded in 2020 compared with the average number of employees over the previous three years. The variable is dichotomous and takes on a unitary value if the number of employees has been reduced in some way, in particular by resorting to unemployment benefits; (3) the number of volunteers; (4) the change in the number of volunteers in 2020, measured by the question "Did the number of volunteers increase during the pandemic?" Respondents could answer "Yes", "No", and "Don't know". A dichotomous variable was created that coded Yes $=1, \mathrm{No}=0$. "Don't know" responses were recoded as missing values and excluded from the analysis; (5) the change in service delivery was measured by the question "Did the organization make a change in service delivery during the crisis?" Three options were proposed: "The organization has provided new services", "The organization has provided traditional services through new modes of delivery" and "The organization has not made any change to its service provision options and modes". Two dummy variables ( $5 \mathrm{a}$ and $5 \mathrm{~b}$ in Table 1 ) have been operationalized using the "The organization has not made any changes to its services" prompt as the benchmark. As controls, we consider: the amount of net assets, expressed in euros; the age of the organization, expressed in years; the temporary suspension of the activities depending on the following options: "The business was never suspended during the crisis", "The organization has experienced periods of interruption and resumption of business in its operations" and "The business has been suspended for the entire period of the crisis".

The dependent variables of interest in the logistic regressions include a dummy that was chosen after considering the results of the OLS regressions. Options related to changes in service delivery are statistically significant to varying degrees for cooperatives and other NPOs in reducing negative economic results, and thus in improving resilience and the ability to withstand crisis. In particular, the choice of providing new services is the relevant outcome in the case cooperatives ( 1 if the supply of new services has taken place, 0 otherwise). On the contrary, the choice to provide existing services through new delivery methods is the dependent variable in the case of other NPOs ( 1 if new delivery methods have been implemented, 0 otherwise). Organizations that did not make any changes to service provision were excluded from the analysis.

We then consider four explanatory dimensions describing the degree of organizational flexibility and include them in both logistic regressions. Two variables capture organizational flexibility in terms of adaptability in decision making. Specifically: (1) the degree of participation in decision-making related to the change in services was measured by three options "It was exclusively decided by the governing bodies of the organization", "It was proposed by the employees and then accepted by the governing bodies", or "It was a fully shared decision among all the organization's members". The variable was operationalized as two dummies (1a and $1 \mathrm{~b}$ in Table 2) with the "Decision by the governing bodies" serving as benchmark; (2) the timeliness of the decision-making process, measured by the question: "When were the changes in service delivery introduced?". Response options were: "As soon as the lockdown started", "During the summer of 2020", or "Later". An ordinal categorical variable was created taking the value 1 if the changes started at the beginning of the lockdown, 2 if it started in the summer, and 3 if it started later. Organizational adaptability is described by two variables: (3) the adaptability of employees' and volunteers' competencies measured by the proxy "Difficulties in changing the modalities of service delivery", on a Likert scale ranging from 1 (low difficulty) to 3 (high difficulty); (4) the adaptability of the organization of work was described by the question: "What

${ }^{5}$ http://serviziorps.regione.marche.it, accessed 12.07.2021. 
Table 1. OLS Regression Results

\begin{tabular}{|c|c|c|}
\hline & Model 1 Social Cooperatives & Model 2 Other non-profit entities \\
\hline & Coeff. (St.Dev.) & Coeff. (St.Dev.) \\
\hline (Intercept) & $49.876^{\star * *}(2.790)$ & $51.478^{\star * *}(1.930)$ \\
\hline \multicolumn{3}{|c|}{ HP1.A. Employment Level and Variation } \\
\hline 1. Number of employees & $0.182(0.111)$ & $1.050^{\star * \star}(0.143)$ \\
\hline 2. Employees' variation (decrease) & $-4.657^{\star \star}(1.777)$ & $-9.328^{\star * *}(0.990)$ \\
\hline \multicolumn{3}{|c|}{ HP1.B. Presence and Variation of Volunteers } \\
\hline 3. Number of volunteers & $-0.167^{\star * \star}(0.063)$ & $-0.093^{* * *}(0.035)$ \\
\hline 4. Volunteers' variation (increase) & $-4.016^{* * *}(1.450)$ & $1.244(0.949)$ \\
\hline \multicolumn{3}{|c|}{ HP1.C. Service innovation } \\
\hline 5a. New ways of delivering traditional services & $-3.312(2.553)$ & $-3.612^{* *}(1.630)$ \\
\hline 5b. New services & $-5.395^{\star \star}(2.613)$ & $-2.395(1.781)$ \\
\hline \multicolumn{3}{|c|}{ Controls } \\
\hline Seamless work activity & $-3.926^{* * *}(1.412)$ & $-0.904(0.932)$ \\
\hline Organization's age & $-0.148^{\star *}(0.071)$ & $0.086^{\star *}(0.039)$ \\
\hline Amount of net assets & $-0.00001^{\star \star}(0.00000)$ & $-0.00001^{\star *}(0.00000)$ \\
\hline $\mathrm{R}^{2}$ & 0.422 & 0.372 \\
\hline f-statistics & $8.531^{\star * *}$ & $16.166^{* * *}$ \\
\hline Number of observations & 115 & 256 \\
\hline \multicolumn{3}{|c|}{ Significance codes: ${ }^{* * *} \mathrm{p}<0.001,{ }^{* *} \mathrm{p}<0.01,{ }^{*} \mathrm{p}<0.05$} \\
\hline \multicolumn{3}{|c|}{ Absence of multicollinearity was verified using the variance inflation factor. } \\
\hline Source: authors. & & \\
\hline
\end{tabular}

pattern of work organization better describes your organization during the COVID-19 pandemic?" The response options were: "Work groups with fixed team members and variable tasks"; "Work groups with variable team members and variable tasks"; "Individual work with variable tasks"; and "Individual work with fixed tasks". Increasing levels of work organization flexibility ranging from 1 (individual work with fixed tasks) up to 4 (work groups with fixed team members and variable tasks) are introduced in one ordinal categorical variable (1 to 4). Finally, two dummies control for the field of operation: culture and education, and healthcare and social assistance, taking the other activities as a benchmark.

The binomial logistic regression is formally described by the following relationship in Equation (1):

$\operatorname{Logit}(p)=\log \left(\frac{p(y=1)}{1-p(y=1)}\right)=\beta_{0}+$

$+\beta_{1 i}$ Dec $+\beta_{2 i}$ Adapt $+\beta_{3 i} X+u_{i}$,

in which the dependent binary variable refers to the choice of providing new services in cooperatives (Model 3) and existing services through new delivery methods in other NPOs (Model 4). Dec represents the decision-making process variables; Adapt the adaptability of the organizational model variables; $\mathrm{X}$ - control variables. The coefficients, estimated with maximum likelihood, describe the effect of each independent variable on the log of the odds ratio, while $u_{i}$ is the residual error.

\section{Results}

The results of the OLS regressions and the diagnostic tests are shown in Table 1.

The results of the OLS regressions show that the number of employees is significant and positively related to the variation of the cost-revenue balance in other NPOs (Model 2, 1.050, $\mathrm{p}<0.001$ ). This means that in the case of other NPOs, a higher number of employees increases the likelihood of a higher costs-revenue balance. Decreasing the number of employees improves economic results during the pandemic, , but this effect is much weaker in cooperatives than other NPOs (-4.657, $\mathrm{p}<0.01 ;-9328, \mathrm{p}<0.001$ respectively). These two results imply that the cooperative business model is more resilient to crisis in terms of labor relations than other NPOs, since the preservation human capital (lower number of layoffs) in cooperatives, irrespective of their dimension, has a negative but smaller impact on economic results. This result can be achieved by making labor costs flexible and reducing them during crisis, which signals better organizational adaptability [Bonin et al., 1993; Pencavel et al., 2006; Navarra, Tortia, 2014; Albanese et al., 2015]. Hypothesis HP1. A was verified.

The number of volunteers is negatively related to cost increases in both models $(-0.167, \mathrm{p}<0.001 ;-0.093$, $\mathrm{p}<0.001$ respectively for Model 1 and Model 2). Thus, a larger number of volunteers reduces the negative effects of the crisis. This effect is significantly stronger in the case of cooperatives. Along the same lines, an 


\section{Table 2. Logistic Regression for Social Cooperatives}

\begin{tabular}{|c|c|c|}
\hline & $\begin{array}{l}\text { Model } 3 \text { Social cooperatives: introduc- } \\
\text { tion of new services }\end{array}$ & $\begin{array}{l}\text { Model } 4 \text { Other NPOs: provision of existing } \\
\text { services in new ways }\end{array}$ \\
\hline & Coeff. (St.Dev.) & Coeff. (St.Dev.) \\
\hline (Intercept) & $-4.712^{* * *}(1.625)$ & $-6.013^{* * *}(1.280)$ \\
\hline \multicolumn{3}{|c|}{ HP2.A. Decision Making Process } \\
\hline 1a. Fully shared decision making & $2.241^{\star *}(0.881)$ & $2.398^{\star \star \star}(0.604)$ \\
\hline 1b. Employees' decision making & $1.412(1.072)$ & $2.445^{\star * \star}(0.948)$ \\
\hline 2. Decision making timeliness & $-1.037^{\star \star}(0.491)$ & $1.346^{* * *}(0.377)$ \\
\hline \multicolumn{3}{|c|}{ HP2.B. Adaptability of the Organizational Model } \\
\hline 3. Members' competencies adaptability & $0.412(0.439)$ & $-0.620(0.628)$ \\
\hline 4. Work organization adaptability & $0.821^{\star \star \star}(0.254)$ & $2.448^{\star *}(1.199)$ \\
\hline \multicolumn{3}{|c|}{ Controls } \\
\hline Culture and education & $-0.473(0.863)$ & $-0.620(0.628)$ \\
\hline Healthcare and social assistance & $1.371^{\star \star}(0.549)$ & $2.448^{\star *}(1.199)$ \\
\hline Pseudo $\mathrm{R}^{2}$ & 0.336 & 0.327 \\
\hline Wald test & $27.6^{* * *}$ & $41.3^{\star * *}$ \\
\hline Number of observations & 107 & 240 \\
\hline \multicolumn{3}{|c|}{ Significance codes: ${ }^{* * *} p<0.001,{ }^{* *} p<0.01,{ }^{*} p<0.05$} \\
\hline \multicolumn{3}{|c|}{$\begin{array}{l}\text { The dependent variable is a dummy, which takes value } 1 \text { if during the pandemic: (III) the social cooperative provided new services; (IV) the NPO has } \\
\text { introduced new ways of delivering traditional services; } 0 \text { if otherwise. }\end{array}$} \\
\hline \multicolumn{3}{|c|}{$\begin{array}{l}\text { The logit linearity assumption was checked by the Box-Tidwell test; the absence of multicollinearity was verified using the VIF (Variance Inflation Factor). } \\
\text { Source: authors. }\end{array}$} \\
\hline
\end{tabular}

increase in the number of volunteers reduces excess costs, albeit only in the case of cooperatives, showing that this organizational typology may be better able to use volunteer work effectively to reduce other categories of costs $(-4.016, \mathrm{p}<0.001)$. Hypothesis HP1. B is completely verified only in the case of cooperatives. Service innovation in the face of the crisis takes different shapes in the two organizational types. Considering as a benchmark those organizations that did not make any change, new ways of delivering traditional services is negatively related to cost increases in other NPOs $(-3.612, \mathrm{p}<0.01)$ while the introduction of new services has a negative impact upon cooperatives $(-5.395, \mathrm{p}<0.01)$. This result, again, can testify to the better ability of cooperatives to react to negative shocks by innovating services and not only by adapting existing ones. HP1. C is verified, but in different ways for cooperatives and other NPOs.

As concerns control variables, higher amounts of net assets are negatively related to the increase of costs over revenues $(-0.00001, \mathrm{p}<0.01$ for both models). The age of the organization is negatively correlated with the reduction in net revenues in cooperatives $(-0.148, \mathrm{p}<0.01)$, but positively in the other NPOs $(0.086, \mathrm{p}<0.01)$. Therefore, older cooperatives respond better to the pandemic crisis, while age is a negative factor in other NPOs. The variable of seam- less working activities is negatively related to costs increases, but it is statistically significant only in the case of cooperatives showing that the continuity of the production process is more important in this organizational typology $(-3.926, \mathrm{p}<0.001)$.

Table 2 shows the logistic regression results and diagnostic tests, taking the introduction of new services as the relevant outcome in the case of social cooperatives and the provision of existing services in new ways in the case of other NPOs.

With regard to social cooperatives (Model 3), the variables that describe the adaptability of decision making processes are both significant. In particular, participation is positively correlated with the probability of providing new services when decisions are fully shared among stakeholders $(2.241, \mathrm{p}<0.01)$ and worker participation also shows a positive sign, but is not significant, signalling a relatively smaller role for direct employee involvement in strategic decisions. Timely decisions, i.e., interventions in the initial phase of the crisis, increase the probability of introducing new services $(-1.037, \mathrm{p}<0.01)$. Clearly, the adaptability of decision making has positive impacts upon the probability of providing new services and appears consistent with the main organizational characteristic of cooperatives, namely the participation of members and collective action, especially in terms of 
shared decisions. Adaptability and innovation seem to derive from specific working rules and organizational routines incorporated into the organizational model and tested by experience over time. These routines could not be improvized during the pandemic. They had to be fundamentally ready to deal with a sudden crisis and promptly introduce new services [Hodgson, 2003]. Hypothesis HP2. A is confirmed in case of cooperatives. Likewise, the adaptability of the organization of work has a positive impact on the ability to provide new services $(0.821, \mathrm{p}<0.001)$, confirming that organizational resilience and innovation are closely linked to the flexibility of the work process. Hypothesis HP2. B is confirmed only as concerns work organization adaptability. Finally, service innovation is more likely to occur in health and care services, which have been heavily involved at the forefront of the pandemic crisis $(1.371, \mathrm{p}<0.01)$, confirming that creativity is activated and innovation arises out of compression and necessity [Dewey, 1934; Joas, 1990; Sacchetti, Tortia, 2013]. Organizations providing these services have had to adapt to the emergency earlier and in more depth than others.

Concerning other NPOs (Model 4), full member participation and employee involvement increase the likelihood of providing old services in new ways $(2,398, \mathrm{p}<0.001$ and $2,445, \mathrm{p}<0.001$, respectively). Timely decisions, unlike the case of social cooperatives, show that other NPOs have tended to introduce new delivery modes at later stages of the pandemic, not at its outbreak $(1.346, \mathrm{p}<0.001)$. These differences signal that the introduction of new services requires faster and more timely decisions, while other NPOs tend to follow slower and less transformative patterns. Hypothesis HP2. A is confirmed but other NPOs follow a less timely pattern of innovation. Furthermore, the adaptability of the work organization has a positive impact upon the likelihood of innovating the provision of services $(1.637, \mathrm{p}<0.001)$, which confirms the importance of renewing dynamic capabilities to respond to external changes and challenges [Teece, Pisano, 1994; Teece et al., 1997; Blandi, 2018]. Hypothesis HP2. B is confirmed only as concerns work organization adaptability. Finally, as in the case of social cooperatives, health and social assistance are the fields of activity that has witnessed the greatest amounts of innovation in service provision $(2,448$, $\mathrm{p}<0.01)$.

\section{Conclusion}

The arguments developed and the empirical results in this article confirm the already existing knowledge that cooperatives behave differently from other orga- nizational forms in the face of negative environmental events, taking the recent pandemic crisis as a notable example. In the first part of the article, we explain why cooperatives are oriented toward protecting employment levels, human capital, and the size of their economic activity better than strategic assets and financial value. The cooperative firm therefore plays a stabilizing and a-cyclical role thanks to its better ability to absorb shocks and redistribute losses within its borders. Contractual imperfections are internalized and managed internally thanks to dedicated governance rules and organizational routines. The preservation or even expansion of production is made possible by lower costs and fewer layoffs, which allows cooperatives to fill the gaps left by conventional companies and the public sector. Together with other non-profit organizations in the third sector, cooperatives integrate public sector supply and are able to innovate the provision of social and welfare services.

In the empirical part of the study, we compared the economic results of cooperatives and other non-profit organizations in the third sector of the Marche region, and their ability to create and innovate service provision. The comparison shows that cooperatives achieve a higher degree of adaptability and resilience than other NPOs, as they resort less often to layoffs and use voluntary work in a more efficient way. This implies that the negative impact of the pandemic is not projected in the long term and cooperatives are able to preserve their human capital pending recovery, although short-term layoffs can cause losses and the depletion of reserves. A lower fluctuation in employment means that, all things being equal, production is also expected to return faster to pre-crisis levels when demand picks up again. On the innovation front, cooperatives show a marked tendency to react to the crisis by introducing new services, rather than innovating existing ones. This, again, is a sign of resilience, as innovation is seen as a strategic tool that can help the organization overcome tough times and restore long-term sustainability in new proactive ways. Future research will have to systematically compare the behavioral responses of cooperatives with those of other organizational forms, in particular investorowned firms, during and after the crisis. New and more comprehensive (longitudinal) data will enable post-crisis recovery analysis and may help unveil the underlying causal relationships. For example, it will be important to understand whether hysteresis implies that a share of the newly unemployed will find it difficult obtaining a new job. If so, the ability of cooperatives to stabilize employment and preserve their human capital during the crisis will appear all the more valuable. 


\section{References}

Albanese M., Navarra C., Tortia E. (2015) Employer moral hazard and wage rigidity. The case of worker owned and investor owned firms. International Review of Law and Economics, 43, 227-237. https://doi.org/10.1016/j.irle.2014.08.006

Alchian A.A., Demsetz H. (1972) Production, information costs, and economic organization. The American Economic Review, 62(5), 777-795. https://www.jstor.org/stable/1815199

Angelini P., Di Salvo R., Ferri G. (1998) Availability and cost of credit for small businesses: Customer relationships and credit cooperatives. Journal of Banking \& Finance, 22(6-8), 925-954. https://doi.org/10.1016/S0378-4266(98)00008-9

Anheier H.L., Kendall J. (2001) Third Sector Policy at the Crossroads: An International Non-profit Analysis, Abingdon: Routledge. Bartlett W., Cable J., Estrin S., Jones D.C., Smith S.C. (1992) Labour-managed cooperatives and private firms in North Central Italy: An empirical comparison. Industrial Labour Relations Review, 46, 103-118. https://doi.org/10.1177\% 2F001979399204600108

Barua S. (2020) Understanding Coronanomics: The economic implications of the coronavirus (COVID-19) pandemic (MPRA Paper 99693). https://mpra.ub.uni-muenchen.de/99693/, accessed 30.06.2021.

Billiet A., Dufays F., Friedel F., Staessens M. (2021) The resilience of the cooperative model: How do cooperatives deal with the COVID-19 crisis? Strategic Change, 30, 99-108. https://doi.org/10.1002/jsc.2393

Blandi V. (2018) Customer Uncertainty: A Source of Organizational Inefficiency in the Light of the Modularity Theory of the Firm. (Ph.D. Dissertation, Trento Doctoral School of Social Sciences). http://eprints-phd.biblio.unitn.it/3056/, accessed 26.12.2021

Bonin J., Jones D.C., Putterman L. (1993) Theoretical and empirical studies of producer cooperatives: Will ever the twain meet? Journal of Economic Literature, 31, 1290-1320.

Borzaga C., Carini C., Tortia E.C. (2021) Co-operative enterprise anti-cyclicality and the economic crisis: A comparative analysis of employment dynamics in Italy. Annals of Public and Cooperative Economics (online first). https://doi.org/10.1111/ apce. 12337

Borzaga C., Galera G. (2016) Innovating the Provision of Welfare Services Through Collective Action: The Case of Italian Social Cooperatives. International Review of Sociology, 26(1), 31-47. https://doi.org/10.1080/03906701.2016.1148336

Burdín G. (2014) Are worker-managed firms more likely to fail than conventional enterprises? Evidence from Uruguay. ILR Review, 67(1), 202-238. https://doi.org/10.1177\%2F001979391406700108

Burdín G., Dean A. (2012) Revisiting the objectives of worker-managed firms: An empirical assessment. Economic Systems, 36(1), 158-171. https://doi.org/10.1016/j.ecosys.2011.06.003

Cheney G., Santa Cruz I., Peredo A.M., Nazareno E. (2014) Worker cooperatives as an organizational alternative: Challenges, achievement and promise in business governance and ownership. Organization, 21, 591-603. https://doi. org/10.1177\%2F1350508414539784

Commons J.R. (1950) The Economics of Collective Action, New York: Macmillan.

Craig B., Pencavel J. (1993) The objectives of worker cooperatives. Journal of Comparative Economics, 17(2), 288-308. https:// doi.org/10.1006/jcec.1993.1027

Curtis L., Edwards C., Fraser K.L., Gudelsky S., Holmquist J., Thornton K., Sweetser K.D. (2010) Adoption of social media for public relations by nonprofit organizations. Public Relations Review, 36(1), 90-92. https://doi.org/10.1016/j. pubrev.2009.10.003

Dewey J. (1934) Art as Experience, New York: Minton, Balch \& Co.

Didier T., Huneeus F., Larrainc M., Schmukler S.L. (2021) Financing firms in hibernation during the COVID-19 pandemic. Journal of Financial Stability, 53, 100837. https://doi.org/10.1016/j.jfs.2020.100837

Ellis J.E., Colin-Jones A., Zugasti I (2018), Mondragon. Maintaining Resilience through Cooperative Strategies. In: Putting Purpose Into Practice: The Economics of Mutuality (eds. C. Mayer, B. Roche), Abingdon: Routledge, pp. 333-338.

Englehardt C.S., Simmons P.R. (2002) Organizational flexibility for a changing world. Leadership \& Organization Development Journal, 23(3), 113-121. https://doi.org/10.1108/01437730210424057

Feldman M.S., Pentland B.T. (2003) Reconceptualizing organizational routines as a source of flexibility and change. Administrative Science Quarterly, 48(1), 94-118. https://doi.org/10.2307/3556620

Grote G., Weichbrodt J.C., Günter H., Zala-Mezö E., Künzle B. (2009) Coordination in high-risk organizations: The need for flexible routines. Cognition, Technology \& Work, 11, 17-27. https://doi.org/10.1007/s10111-008-0119-y

Hansmann H.B. (1980) The role of nonprofit enterprise. Yale Law Journal, 89, 835-898. https://digitalcommons.law.yale.edu/ cgi/viewcontent.cgi? article=6597\&context=ylj, accessed 30.08.2021.

Hansmann H. (1996) The Ownership of Enterprise, Cambridge, MA: Harvard University Press.

Hansmann H. (2013) All firms are co-operative, and so are governments. Journal of Entrepreneurial and Organizational Diversity, 2, 1-10. https://doi.org/10.5947/jeod.2013.007

Hardin G. (1968) The tragedy of the commons. Science, 162, 3859, 1243-124.

Hatum A., Pettigrew A.M. (2006) Determinants of organizational flexibility: A study in an emerging economy. British Journal of Management, 17, 115-137. https://doi.org/10.1111/j.1467-8551.2005.00469.x 
Hodgson G.M. (2003) The mystery of the routine. The Darwinian destiny of an evolutionary theory of economic change. Revue économique, 54(2), 355-384. https://doi.org/10.2307/3503007

Hoogendoorn B. (2011) Social Entrepreneurship in the Modern Economy: Warm Glow, Cold Feet, Rotterdam: Erasmus University.

Iliopoulos C., Valentinov V. (2018) Cooperative longevity: Why are so many cooperatives so successful? Sustainability, 10, 3449. https://doi.org/10.3390/su10103449

Jensen A.B. (2013) Do we need one business model definition? Journal of Business Models, 1, 61-84._https://doi.org/10.5278/ ojs.jbm.v1i1.705

Jensen M.C., Meckling W.H. (1979) Rights and production functions: An application to labor-managed firms and codetermination. The Journal of Business, 52(4), 469-506. https://www.jstor.org/stable/2352442

ISTAT (2020) Struttura e profili del settore non-profit, Rome: ISTAT. https://www.istat.it/it/files//2020/10/REPORT_ ISTITUZIONI_NONPROFIT_2018.pdf, accessed 29.06.2021 (in Itailan).

Lampel J., Bhalla A., Jha P.P. (2014) Does governance confer organisational resilience? Evidence from UK employee owned businesses. European Management Journal, 32(1), 66-72. https://doi.org/10.1016/j.emj.2013.06.009

Miyazaki H., Neary H.M. (1983) The Illyrian firm revisited. Bell Journal of Economics, 14(1), 259-270. https://doi. org/10.2307/3003552

Mobiny M., Soster-Ramos V. (2020), Motivating and maintaining people in non-profit organizations. Lund: Lund University. http://lup.lub.lu.se/luur/download?func=downloadFile\&recordOId=9013496\&fileOId=9023572, accessed 20.07.2021.

Mori P.A. (2014) Community and cooperation: The evolution of cooperatives towards new models of citizens' democratic participation in public services provision (Euricse WP 63-14). Trento TN: Euricse. https://www.euricse.eu/wp-content/ uploads/2015/03/1393492623_n2497.pdf, accessed 12.06.2021.

Navarra C. (2016) Employment stabilization inside firms: An empirical investigation on worker cooperatives. Annals of Public and Cooperative Economics, 87(4), 563-585. https://doi.org/10.1111/apce.12124

Navarra C., Tortia E. (2014) Employer moral hazard, wage rigidity, and worker cooperatives: A theoretical appraisal. Journal of Economic Issues, 48, 707-726. https://doi.org/10.2753/JEI0021-3624480306

Nelson T., Nelson D., Huybrechts B., Dufays F., O’Shea N., Trasciani G. (2016) Emergent identity formation and the cooperative: Theory building in relation to alternative organizational forms. Entrepreneurship \& Regional Development, 28, 286-309. https://doi.org/10.1080/08985626.2016.1155744

Ostrom E. (1990) Governing the Commons. The Evolution of Institutions for Collective Action, Cambridge, UK: Cambridge University Press.

Ostrom E. (2005) Understanding Institutional Diversity, Princeton, NJ: Princeton University Press.

Pencavel J., Pistaferri L., Schivardi F. (2006) Wages, employment, and capital in capitalist and worker-owned firms. ILR Review, 60, 23-44. https://doi.org/10.1177\%2F001979390606000102

Pérotin V. (2013) Worker Cooperatives: Good, Sustainable Jobs in the Community. Journal of Entrepreneurial and Organizational Diversity, 2(2), 34-47. https://doi.org/10.5947/jeod.2013.009

Poledrini S., Tortia E.C. (2020) Social enterprises: Evolution of the organizational model and application to the Italian case. Entrepreneurship Research Journal, 10(4), 20190315. https://doi.org/10.1515/erj-2019-0315

Roelants B., Sanchez Bajo C. (2011) Capital and the debt trap: Learning from cooperatives in the global crisis. New York: Palgrave.

Sacchetti S., Borzaga C. (2020) The foundations of the "public organisation": Governance failure and the problem of external effects. Journal of Management and Governance (online first). https://doi.org/10.1007/s10997-020-09525-X

Sacchetti S., Tortia E.C. (2013), Satisfaction with creativity: A study of organizational characteristics and individual motivation. Journal of Happiness Studies, 14, 1789-1811. https://doi.org/10.1007/s10902-012-9410-y

Sparviero S. (2019) The case for a socially oriented business model canvas: The social enterprise model canvas. Journal of Social Entrepreneurship, 10, 232-251. https://doi.org/10.1080/19420676.2018.1541011

Teece D.J., Pisano G. (1994) The dynamic capabilities of firms: An introduction. Industrial and Corporate Change, 3(3), 537556. https://doi.org/10.1093/icc/3.3.537-a

Teece D.J., Pisano G., Shuen A. (1997) Dynamic capabilities and strategic management. Strategic Management Journal, 18, 509-533. https://doi.org/10.1002/(SICI)1097-0266(199708)18:7\%3C509::AID-SMJ882\%3E3.0.CO;2-Z

Tortia E.C. (2020) From non-profit organizations to multi-stakeholder social enterprises. In: Corporate Governance: Examining Key Challenges and Perspectives (eds. A. Kostyuk, M.J. Coelho Guedes, D. Govorun), Sumy: Virtus Interpress, pp. 121-130.

Tortia E.C. (2021) Capital as common-pool resource: Horizon problem, financial sustainability and reserves in worker cooperatives. Journal of Co-operative Organization and Management, 9(2), 100137. https://doi.org/10.1016/j. jcom.2021.100137

Weick K., Sutcliffe K.M. (2007) Managing the unexpected: Resilient performance in an age of uncertainty, San Francisco: JosseyBass.

Williamson O.E. (1975) Markets and Hierarchies: Analysis and Antitrust Implications. A Study in the Economics of Internal Organization, New York: Free Press. 